\title{
Organizational Embeddedness Dimensions' Roles in Perceived Career Opportunities: Turnover Intention of Indonesian Millennials
}

\section{Haiti Maria Esterlita and Debora Eflina Purba ${ }^{\mathrm{b}}$}

${ }^{a}$ Faculty of Psychology, Universitas Indonesia, Depok, Indonesia; ${ }^{b}$ Department of Industrial and Organizational Psychology, Faculty of Psychology, Universitas Indonesia, Depok, Indonesia

*Corresponding author:

Debora Eflina Purba

Department of Industrial and Organizational Psychology

Faculty of Psychology, Universitas Indonesia

Depok, Jawa Barat, Indonesia

Email address: eflina@ui.ac.id 


\title{
Organizational Embeddedness Dimensions' Roles in Perceived Career Opportunities: Turnover Intention of Indonesian Millennials
}

\begin{abstract}
This study investigated mediating effects of organizational embeddedness's dimensions (fit, links, and sacrifice) in the relation between perceived career opportunity (PCO) and turnover intention. Using resource theory, the study argues that individuals with high PCO would feel they fit into an organization because career opportunities it provides accord with their career goals. Employees would then be motivated to build social relationships in organizations and, conversely, would feel burdened by leaving the organization, in turn, leading to low levels of turnover intention. Data were collected among employees of various organizations in Jakarta and surroundings $(\mathrm{N}=311)$; these data were analyzed using the mediation technique with the Hayes PROCESS macros on SPSS v. 21. Results showed that fit and sacrifice dimensions mediated the relation between $\mathrm{PCO}$ and turnover intention, but the links dimension did not. Links mediated the PCO and turnover intention only when combined with fit and sacrifice. Theoretical and practical implications are then discussed.
\end{abstract}

Keywords: organizational embeddedness, perceived career opportunity, turnover intention, millennials

\section{Introduction}

Employees are the most valuable asset supporting an organization in achieving its goals, so a successful organization must focus on retaining productive employees. Michael Page Indonesia Employee Intentions Report (2015) conducted a study with 500 employees in Indonesia and reported that 72 percent of participants planned to leave their organizations within the next 12 months. Ertas (2015) compared employee turnover of millennials and older generations in United States (US) federal agencies. Results showed that each generation (Baby Boomer, Generations $\mathrm{X}$ and $\mathrm{Y}$ ) has significant turnover differences, that is, millennial workers (Gen Y, born from 1981 to 1999) were more likely to report the intention to leave their jobs than older workers. The present study was conducted specifically on millennial employees because previous research stated that by 2015, millennials would exceed $50 \%$ of the total workforce (Dwaikat, Queiri, \& Yusoff, 2014). According to Banister, Meriac, and Woehr (2010), Gen Y employees had the highest turnover intentions compared to older generations (Baby Boomers and Gen X), that is, 31\% versus 24\% (Ertas, 2015; Tramonte, 2012; Hisham, Queiri, Yusoff, \& Zakaria, 2013).

Employee turnover, especially voluntary turnover, negatively impacts organizations because they have invested money, time, and effort to develop their employees (Bravo, Kraimer, Liden, Seibert, \& Wayne, 2011). Aamodt (2010) stated that employee turnover could cost an organization about 1.5 times the salary, which is divided into two, that is, visible costs (e.g., advertising, employment agencies, recruitment fees, salaries) and invisible costs, (e.g., level of organizational productivity due to vacant positions). The best predictor and main triggers of actual turnover are turnover intentions (Allen, Moffitt, \& Weeks, 2005; Griffeth, Hom, Lee, \& 
Mitchell, 2012; Henneberger \& Sousa-Poza, 2004). Therefore, this study focuses on turnover intentions, which indicate the possibility of changing jobs for a certain period of time (Henneberger \& Sousa-Poza, 2004). Because of employee turnover risks, described above, organizations need to identify factors that affect turnover intention, so they can prevent voluntary turnover conditions (Born, Oostrom, Purba, \& van der Molen, 2016). Previous research on turnover intention has identified many factors: among others are demographic predictors (age, gender), work-related predictors (stress, burnout, career, job demand), attitudes and perceptions (job satisfaction, organizational commitment, job embeddedness, perceived career opportunity), and work environment predictors (Hisham et al., 2013; Jiang, Liu, Mitchell, McKay, \& Lee, 2012; Kao \& Kim, 2014; Bakker \& Schaufeli, 2004).

This study focuses on perceived career opportunities (PCO) as a predictor of turnover intention for millennials because they value personal development, especially development opportunities that match their career interests (Chi, Gursoy, \& Maier, 2008). This is supported by previous research findings that one cause of millennials' high turnover intention is that their commitment lies in their career itself rather than in the organization (Hisham et al., 2013; Arruda, 2017; Harris, 2016). Bravo et al. (2011) investigated predictive validity of PCO on turnover, over and above job satisfaction, organizational commitment, career-related perceived organizational support, perceived external job alternatives, and organizational support for development. Our study contributes to the literature by showing the mediating role of job-embeddedness dimensions - fit, links, and sacrifice — on PCO-turnover relations.

\section{Perceived Career Opportunity and Turnover Intention}

Bravo et al. (2011) explained that employees might be motivated to maintain high job performance to obtain a future job position that fits their career goals. In other words, when employees feel there are significant career opportunities for them in an organization, they have greater motivation to work for the organization's benefit. Employees' perception of career opportunities in the organization is called PCO, defined as employees' perception of the extent to which job assignments and job opportunities matching their career interests and goals are available in their current organization (Bravo et al., 2011). The PCO construct differs from other constructs, such as perceived organizational support-career (POS-career), perceived career plateau, and satisfaction with promotion (Bravo et al., 2011). POS-career, career plateau, and satisfaction with promotion focus on hierarchical career support provided by the organization and its procedural fairness, while PCO does not specifically consider desire for hierarchical promotion. Unlike other career-related constructs, PCO construction is based on the idea that every employee has career goals and interests that might or might not be provided by the organization, regardless of its level of career support, job movement, or the equality of the process of obtaining a particular position (Bravo et al., 2011). Consistent with the definition, items of the PCO instrument measure the extent to which employees perceive job opportunities within an organization that match their career goals and interests.

According to Eisenberger and Rhoades (2002), when employees perceive that their organization is concerned about their well-being and appreciate their contributions, they likely increase their commitment, loyalty, and performance. Huber (2017) explains that if employees believe that 
their organization does not have career opportunities aligned with their career goals, they might tend to leave the organization looking for opportunities elsewhere. Erez, Holtom, Lee, Mitchell, and Sablynski (2001) supported the statement with their findings that when organizations provide development support that prepares employees for what they perceive as attractive career opportunities, employees are motivated to stay with their current employer because career opportunities tend to embed employees within the organization. Turnover would represent the sacrifice of a valued outcome related to the employee's career goals. To our knowledge, research examining the relation between PCO and turnover intention is still lacking. Only one study has examined it, Bravo et al. (2011), who found that employees with high PCO tend to stay with an organization. We used social exchange theory to explain the relation between PCO and turnover intentions. Blau (1964) defined social exchange theory as an exchange activity, tangible or intangible, resulting in benefits between at least two people. Support perceived by employees can be a way of generating social exchange with benefits of reciprocal behaviors, such as high levels of citizenship behavior, job performance, and low levels of turnover intention (Baer, Colquitt, Halvorsen-Ganepola, \& Long, 2014). Applying the theory to our study, we argue that when employees perceive that the organization provides desirable career opportunities, then, as reciprocity, they continue to work there longer. This is supported by previous research that career growth and career-growth opportunities provided by organizations are negatively related to employee turnover intention (Bedeian, Kemery, \& Pizzolatto, 1991; Ashkanasy, Lievens, McElroy, Wang, \& Weng, 2014).

\section{The Role of Organizational Embeddedness as Mediator}

A previous study found that PCO was predictive of turnover, over and above other job attitudinal and perceptual variables (Bravo et al., 2011). When employees perceived more career opportunities within an organization, they were less likely to leave. Erez et al. (2001) supported the statement with their findings that when organizations provide attractive career opportunities, employees are motivated to stay with the current employer. Although research examining the relation between $\mathrm{PCO}$ and turnover intentions is still scarce, we argue that it is indirect. We use conservation of resource theory by Hobfoll (1989) as the underlying theory in explaining the mediating effect of job embeddedness in PCO-turnover intention relations. The basic principle of COR theory is that a person strives to defend, protect, and build their resources and feels threatened if they lose resources (Hobfoll, 1989). Resources can be in the form of a state or conditions (e.g., status within the organization), personal resources (e.g., self-esteem), energy resources (e.g., money or time), and object resources (e.g., material assets) (Harris, Kacmar, \& Wheeler, 2011). Therefore, PCO is perceived as organizational resources that employees value and are likely to protect, therefore, embedding employees in the current organization. Erez et al. (2001) defined job embeddedness as the whole of factors that make employees unwilling to leave their jobs. Job embeddedness consists of organizational embeddedness, defined as factors in the organization that attach employees to the organization, and community embeddedness, defined as factors in the community where employees live that encourage employees to stay with the organization (Erez et al., 2001). This study focuses on organizational embeddedness for two reasons. First, our participants are millennials, and most of them do not have their own houses. Hence, community embeddedness is not relevant to their situation. Second, PCO 
examines individual perception of the organization, and, therefore, organizational embeddedness is more relevant to our study than community embeddedness.

Three dimensions of organizational embeddedness are critical in attaching employees to work or an organization, namely fit, links, and sacrifice (Erez et al., 2001). Organizational fit is defined as the employee's felt value, career goals, and future plan consistent with the reality of a career in the organization. Organization links are formal or informal connections between employees and coworkers, such as relationships with colleagues, work groups, supervisors, and so on. Organizational sacrifice refers to the cost and psychological benefits an employee would gain by leaving the organization, such as sacrificing co-workers, benefits, projects, rewards, job stability, and promotion. Most previous research has focused mostly on second-order factors of job embeddedness, in which fit, links, and sacrifice dimensions were measured as one variable. Only a handful of studies separate job embeddedness into its dimensions (Burch, Lee, \& Mitchell, 2014). Lee and colleagues further contended that studying each dimension of job embeddedness is valuable because studies previously found different relations between those dimensions and other variables across studies. Thus, in the present study, we examine the mediating effect of each dimension of job embeddedness.

Previous studies suggested that having personal attributes that fit the employee's job may decrease turnover and that lack of compatibility predicted turnover (Chan, 1996; Bernardin, Dahmus, Johnson, \& Villanova, 1994). If we apply the COR theory to our study, resources owned by employees are career opportunities that embed employees in the organization because they experience fit or congruency between their personal values and organizational values (organizational fit) (Halbesleben, Neveu, Paustian-Underdahl, \& Westman, 2014). Thus, when employees perceive that an organization provides interesting career opportunities that match their career goals, they feel comfortable with the organization because it is perceived to support their values, career goals, and future plans. This, in turn, leads to low levels of turnover intention. Therefore, we hypothesized the following:

\section{Hypothesis 1: The fit dimension mediates the relation between PCO and turnover intention.}

The wider the links the employee has, the more he or she is embedded in the organization (Erez et al., 2001). High PCO employees tend to be better at establishing formal and informal connections within the organization (organizational links) because they are more active in searching for opportunities (compared to low PCO employees), resulting in more links being established. Thus, when individuals perceive that the organization provides job opportunities that are attractive, interesting, and match their career goals, they are motivated to expand links that can support their career in the organization. The broader the individuals' links, the more difficult for individuals to leave the organization because leaving means they must develop new links within the new organizational environment. Therefore, they have low levels of turnover intention, and we hypothesize the following: 


\section{Hypothesis 2: The links dimension mediates the relation between PCO and turnover intention.}

Sacrifice explains perceived material costs or psychological benefits that might be lost if the employee leaves the job. For example, leaving an organization means personal losses like losing a colleague, handing over an interesting project, or losing an allowance (Erez et al., 2001). Employees with high PCO are unwilling to lose their career opportunities if they must leave the organization (organizational sacrifice), thus attaching them more to the organization (Halbesleben et al., 2014). In other words, when individuals perceive that the organization provides job opportunities that are attractive, interesting, and match their career goals, they feel reluctant to leave the organization because leaving means they must sacrifice valued resources provided by the organization, so individuals become attached to the organization and reduce turnover intention.

\section{Hypothesis 3: The sacrifice dimension mediates the relation between PCO and turnover intention.}

Lastly, we argue for a combined mediating effect of fit, links, and sacrifice dimensions in PCO and turnover intention relations. Again, based on conservation resources theory (Hobfoll, 1989), we hypothesize that - together - fit, links, and sacrifice mediate the relation between PCO and turnover intention. Specifically, we expect that higher PCO would be associated with increased fit, increased links, and increased sacrifice which, in turn, would be related to a low level of turnover intention.

Based on this explanation, we hypothesize the following:

Hypothesis 4: Fit, links, and sacrifice dimensions mediate the relation between PCO and turnover intention.

\section{Methods}

\section{Participant and Procedures}

Participants in this study were employees born from 1981 to 1999 (Banister et al., 2010), working in Jakarta and surroundings, Indonesia. We focus on Gen Y employees because they already dominate the organizational workforce and they have the highest turnover intention compared to older generations (Baby Boomers and Gen X) (Ertas, 2015; Dwaikat et al., 2014; Tramonte, 2012; Hisham et al., 2013). Participants had worked in the organization for at least 6 months because within 6 months, employees are considered to have organizational socialization, and therefore they already recognize the supports provided. Additionally, we narrowed the level of employee education to the minimum of a bachelor's degree or the equivalent because we assume employees who have finished college have a clearer career plan and already know their career interests. 
We recruited participants with the nonprobability sampling technique because we did not know the exact population number and could not identify anyone who is a member of the population (Forzano, \& Gravetter, 2012). Therefore, we could not be sure each member of the population had an equal opportunity to be selected, thus causing vulnerability to bias. We used convenience and accidental sampling types. In both types, participants were selected based on their availability and willingness to be participants (Forzano \& Gravetter, 2012). We conducted the study with an online survey by directly asking our acquaintances to distribute the survey link to their friends. We also spread the survey with a short message, as an invitation through social media (Line, WhatsApp, Facebook, and Instagram). We ensured participants that their data would remain confidential and that their participation was voluntary.

Of 322 participants who responded, we eliminated 11 from analyses because they did not meet specified criteria. Thus, total participants were 311 (58.2\% female). Their mean age was 25.81 $(S D=3.80)$, and the majority held bachelor's degrees $(85.5 \%)$.

\section{Measurements}

Perceived Career Opportunity was measured using the three-item PCO instrument (Bravo et al., 2011), which was translated and back-translated from English to Bahasa Indonesia by two bilingual people and reviewed by an industrial and organizational psychologist. The measurement used a 5-point Likert scale $(1=$ strongly disagree to $5=$ strongly agree $)$. An example item is "There are career opportunities within [Company] that are attractive to me" ( $\alpha$ $=0.80)$.

Organizational Embeddedness was measured using the 13-item Organizational Embeddedness scale by Purba (2015). It contains five items on organizational fit, four items on organizational links, and four items on organizational sacrifice. The measurement used a 5point Likert scale $(1=$ strongly disagree to $5=$ strongly agree $)$. Coefficient alphas were 0.85 for fit, 0.73 for links, and 0.82 for sacrifice. Example items are: "I feel like I am a good match for this organization" (organizational fit); "I interact quite intensely with my coworkers every day" (organizational links); and "If I leave this organization, I will lose structure in my life" (organizational sacrifice).

Turnover intention is measured with a scale used by Atan and Purba (2018), adapted from Mobley's (1978) scale. This measuring tool consists of three items scaled from strongly disagree to strongly agree. The measurement used a 5-point Likert scale $(1=$ strongly disagree to $5=$ strongly agree $)$. An item example is "I will leave this organization" $(\alpha=0.90)$.

\section{Test of Common Method Variance}

All this study's variables were obtained from the same source (self-report) or using the same method, thus increasing the probability of common method bias, an error due to the method of measurement, not because two constructs correlate (Lee, MacKenzie, Podsakoff, \& Podsakoff, 2003). To avoid common method bias, the questionnaire's preface states that there are no right or wrong answers and guarantees the confidentiality of respondent data. Furthermore, we performed a common method bias test. We used Harman's single-factor test, finding five factors 
of 19 items that had more than one eigenvalue; it showed that the first factor had $37.50 \%$ of the variance. If the first factor contains more than $50 \%$ of the variance, then common method variance (CMV) might cause common method bias. Since this study's first factor was far below $50 \%$, the possibility of CMV affecting this research was very small.

\section{Confirmatory Factor Analyses (CFA)}

Table I. Results of Confirmatory Factor Analysis $(\mathrm{N}=311)$

\begin{tabular}{lllllll}
\hline Model & Latent variables & $d f$ & $\chi^{2}$ & CFI & RMSEA & SRMR \\
\hline One factor model & General factor & 152 & 1025.325 & 0.67 & 0.14 & 0.10 \\
$\begin{array}{l}\text { Three factor } \\
\text { model }\end{array}$ & $\begin{array}{l}\text { Organizational embeddedness, PCO, } 149 \\
\text { Furnover intentions }\end{array}$ & 702.723 & 0.79 & 0.10 & 0.09 \\
& $\begin{array}{l}\text { Fit, Links, Sacrifice, PCO, Turnover } \\
\text { intentions }\end{array}$ & 142 & 268.800 & 0.95 & 0.05 & 0.06 \\
\hline
\end{tabular}

a. Notes. PCO (Perceived Career Opportunity), CFI = Comparative Fit Index, RMSEA=Root Mean Square Error of Approximation,

b. SRMR=Standard Root Mean Square Residual.

We conducted CFA using the Lavaan package ver. $0.5-22$ in $\mathrm{R}$ ver. 3.2.3 to assess discriminant validity of the study's constructs [37]. We used the following cut-off criteria to assess fit between hypothesized models and data: CFI $>0.95$, RMSEA $<0.06$, and SRMR $<0.08$ (Bentler $\& \mathrm{Hu}, 1999)$. Results of CFAs are reported in Table 1.

We compared the proposed five-factor model (fit, links, sacrifice, PCO, and turnover intention as latent variables) with alternative models: a one-factor model, in which all items load onto one latent variable and a three-factor model (including organizational embeddedness as unidimensional and PCO as latent variables).

The result showed that the one-factor model did not meet all cut-off criteria, the three-factor model met one of three cut-off criteria, and the five-factor model met all three cut-off criteria $\left(\chi^{2}\right.$ $(142)=268.800, \mathrm{p}<0.000, \mathrm{CFI}=0.95$, RMSEA $=0.05, \mathrm{SRMR}=0.06)$. It showed that the fivefactor model is better than the two alternative models; organizational embeddedness (fit, links and sacrifice), PCO and turnover intentions are the five distinct factors in this model.

\section{Results}

Table 2 presents all study variables' means, standard deviations, and correlations. We found significant negative relation between age and turnover intention $(r=-0.26, p<0.01)$. Job tenure had positive significant relation with turnover intention $(r=-0.13, p<0.05)$. Thus, we controlled for age and job tenure in our further analyses. Furthermore, PCO had significant negative relation with turnover intention $(r=-0.56, p<0.01)$. PCO also significantly and positively related with fit, links, and sacrifice dimensions $(r=0.62, p<0.01 ; r=0.23, p<0.01$; $r=0.39, p<0.01$; respectively). Finally, turnover intention was significantly and negatively related to fit, links, and sacrifice dimensions $(r=-0.63, p<0.01 ; r=-0.10, p<0.01 ; r=-0.47$, $p<0.01$; respectively). 
Table II. Means, Standard Deviations, and Correlations among Study Variables

\begin{tabular}{|c|c|c|c|c|c|c|c|c|c|c|c|c|}
\hline Variable & $M$ & $S D$ & 1 & 2 & 3 & 4 & 5 & 6 & 7 & 8 & 9 & 10 \\
\hline 1. Age & 25.81 & 3.80 & - & & & & & & & & & \\
\hline 2. Gender & 1.58 & 0.49 & -0.11 & - & & & & & & & & \\
\hline $\begin{array}{l}\text { 3. Degree } \\
\text { 4. Job }\end{array}$ & 2.03 & 0.38 & $0.32 * *$ & -0.07 & - & & & & & & & \\
\hline Tenure & 28.09 & 27.27 & $0.72 * *$ & -0.01 & $0.25^{* *}$ & - & & & & & & \\
\hline 5. $\mathrm{PCO}$ & 3.33 & 0.83 & 0.81 & $-0.15^{* *}$ & $0.12 *$ & 0.08 & $(0.80)$ & & & & & \\
\hline 6. OEF & 3.61 & 0.67 & $0.16^{* *}$ & -0.09 & $0.05^{*}$ & $0.12 *$ & $0.62 * *$ & $(0.85)$ & & & & \\
\hline 7. OEL & 3.80 & 0.63 & 0.08 & 0.05 & 0.10 & $0.12 *$ & $0.23 * *$ & $0.30 * *$ & $(0.73)$ & & & \\
\hline 8. OES & 2.80 & 0.88 & 0.07 & -0.06 & $0.14 *$ & 0.02 & $0.39 * *$ & $0.45^{* *}$ & $0.27 * *$ & $(0.82)$ & & \\
\hline 9. JE & 3.42 & 0.54 & $0.14^{*}$ & -0.05 & $0.13^{*}$ & 0.11 & $0.57 * *$ & $0.80 * *$ & $0.63^{* *}$ & $0.80^{* *}$ & $(0.84)$ & \\
\hline 10. TOI & 3.21 & 1.09 & $-0.26 * *$ & 0.07 & -0.07 & $-0.13 *$ & $-0.56 * *$ & $-.63 * *$ & -0.10 & $-0.47 * *$ & $-0.56 * *$ & $(0.90)$ \\
\hline
\end{tabular}

Notes. $\mathrm{N}=311$. Age was measured in years; Gender was dummy-coded ( $1=$ male, $2=$ female); Job tenure is measured in months; Degree was dummy-coded ( 1 = Diploma, 2 = Bachelor's Degree, 3 = master's degree). All other scales were measured on a 5 -point scale. The number in diagonal line is Cronbach's Alpha of each measuring. $\mathrm{PCO}=$ perceived career opportunity. OEF = Organizational Embeddedness Fit. OEL $=$ Organizational Embeddedness Links. OES = Organizational Embeddedness Sacrifice. JE $=$ Job Embeddedness. TOI $=$ Turnover Intentions $* * p<0.01,{ }^{*} p<0.05$. The number on the diagonal is Cronbach's Alpha of each measuring instrument.

To test the hypothesis on the mediating effect of fit, links, and sacrifice dimensions in the relation between PCO and turnover intention, serial multiple mediation analysis was conducted. We used the Hayes PROCESS macro on SPSS v.21, a tool that integrates the functionality of existing and published statistical tools for mediation analysis and moderation analysis. We chose this tool because it allowed us to test indirect effects between variables. The test of the mediation model was conducted by applying 10.000 bootstrap samples with a bias corrected confidence interval. Confidence Intervals (CI) determine whether research results are significant. If CI do not include zero, then the effect is significant.

Table III. Direct and Indirect Effects between Perceived Career Opportunity and Turnover Intentions for Serial Mediation $(\mathrm{N}=311)$

\begin{tabular}{lrrrr}
\hline Mediating Variable & \multicolumn{3}{c}{ Perceived Career Opportunity } \\
\cline { 2 - 5 } & Effect & Boot & \multicolumn{1}{l}{ Boot } & \multicolumn{2}{c}{ Boot } \\
& & SE & LLCI & \multicolumn{1}{l}{ ULCI } \\
\hline Total Effect & -0.71 & 0.06 & -0.84 & -0.59 \\
Direct Effect & -0.33 & 0.08 & -0.48 & -0.18 \\
Indirect Effect & -0.38 & 0.06 & -0.50 & -0.28 \\
(Total) & & & & \\
$\quad$ Indirect Effect of PCO on TOI through fit & -0.31 & 0.05 & -0.42 & -0.23 \\
$\quad$ Indirect Effect of PCO on TOI through links & 0.01 & 0.01 & -0.01 & 0.05 \\
$\quad$ Indirect Effect of PCO on TOI through sacrifice & -0.05 & 0.02 & -0.11 & -0.01 \\
$\quad$ Indirect Effect of PCO on TOI through fit and links in serial & 0.03 & 0.01 & 0.01 & 0.06 \\
$\quad$ Indirect Effect of PCO on TOI through fit and sacrifice in serial & -0.05 & 0.02 & -0.09 & -0.02 \\
Indirect Effect of PCO on TOI through links and sacrifice in serial & -0.00 & 0.00 & -0.01 & 0.00 \\
$\quad$ Indirect Effect of PCO on TOI through fit, links and sacrifice in & -0.01 & 0.00 & -0.02 & -0.00 \\
$\quad$ serial & & & & \\
\hline
\end{tabular}


Results in Table 3 show that the total PCO effect on turnover intention is negative and significant (total effect $=-0.71, \mathrm{SE}=0.06,95 \%$ CI $[-0.84,-0.59]$ ). After fit, links, and sacrifice dimensions were included in the model, the direct PCO effect on turnover intentions was still negative and significant (direct effect $=-0.33, \mathrm{SE}=0.08,95 \% \mathrm{CI}[-0.48,-0.18]$ ). Hypothesis 1 stated that fit dimension mediates the relation between PCO and turnover intention. Table 3 also shows that indirect $\mathrm{PCO}$ effect on turnover intention via fit dimension is significant (indirect effect $=-0.31, \mathrm{SE}=0.05$, CI 95\% $[-0.4184,-0.2251])$, supporting Hypothesis 1 . Hypothesis 2 stated that the links dimension mediates the relation between PCO and turnover intention. Table 3 shows that the links dimension did not mediate the relation (indirect effect $=0.01, \mathrm{SE}=0.01$, CI 95\% [-0.0075, 0.0493]). Therefore, our data did not support Hypothesis 2. Hypothesis 3 stated that the sacrifice dimension mediated the relation between PCO and turnover intention. Results show that sacrifice mediated the relation (indirect effect $=-0.05, \mathrm{SE}=0.02$, CI 95\% $[-0.1058,-0.0144)$, supporting Hypothesis 3. Lastly, Hypothesis 4 stated that fit, links, and sacrifice dimensions mediated the relation between PCO and turnover intention. Our results show that fit, links, and sacrifice dimensions mediated the relation between PCO and turnover intention (indirect effect $=-0.01, \mathrm{SE}=0.00$, CI 95\% $[-0.0166,-0.0017]$ ), supporting Hypothesis 4.

\section{Discussion}

This study examined the mediating effect of each organizational-embeddedness dimension in the relation between PCO and turnover intention. Our results showed that fit, links, and sacrifice mediated the relation between PCO and turnover intention. These findings align with Hobfoll's (1989) COR theory that a person attaches to an organization to avoid losing valuable resources, in this case, the organization's career opportunities, and then, chooses to remain in the organization (Halbesleben et al., 2014). Below, we structure our discussion based on hypotheses order.

First, our results showed that fit dimension mediated the relation between PCO and turnover intention. These findings support previous research that when employees' personal attributes fit their jobs, it may decrease turnover (Chan, 1996; Bernardin et al., 1994). Furthermore, organizational career opportunities that match employee career goals increase employees' feelings of fitness to the organization and decrease turnover intention. Other than that, our results showed that the fit dimension related to turnover intention. These findings support previous research that when employees feel their jobs are not in line with their career goals, they tend to leave the organization (Huber, 2017). Second, we found that links did not have a significant relation with turnover intention and did not have a mediation effect in the PCO-turnover intention relation; links do not necessarily determine an employee's intention to stay in an organization.

Third, our result proved that sacrifice mediated the relation between PCO and turnover intention. Employees' career opportunities are considered a resource that makes them unwilling to leave the organization (Halbesleben et al., 2014). This study showed that employees who perceive an organization as providing career opportunities that match their career goals feel burdened by 
leaving an organization because they must sacrifice their valuable resource (career opportunities).

Interestingly, we found that the links dimension mediated the relation only when considered with fit and sacrifice dimensions. These findings proved our last hypothesis that links and sacrifice mediated the PCO-turnover intention relation. Our study implies that when employees perceive the organization providing support as attractive career opportunities, they feel comfortable working there and are motivated to develop links to other employees. This would, in turn, lead to their reluctance to sacrifice the feeling of fit and links they have developed, and thus, to low levels of turnover intention.

Our study contributes to the literature by showing underlying psychological processes of organizational embeddedness dimensions, namely fit, links, and sacrifice, in the relation between PCO and turnover intention. Furthermore, previous research has rarely considered each dimension of job embeddedness in their relations with other job variables, albeit previous research has found different relations between each dimension of job embeddedness and other variables (Cordery, Gamble, \& Tian, 2016). Thus, we contributed to the literature by showing that each dimension has a different relation with PCO and turnover intention.

We also contributed to the literature by focusing on millennial employees, who were found to have high turnover intention when they feel they have little chance of advancing their careers (Arruda, 2017; Harris, 2016). As far as we know, this was the first study to examine career perceptions of millennials in Indonesia, and it has deepened understanding of perceptions regarding millennial employees who now dominate the workforce. Although previous research has proven that career development is important for millennial employees, this study specifically showed that in developing careers, the organization should pay attention to whether potential careers match employees' PCO.

\section{Practical Implications}

Our research has a few practical implications for organizations. That millennial employees view career opportunities as important can be an organizational consideration, in that organizations should be sensitive to millennial employees' PCO. Thus, as part of HR practices, organizations can create clear career opportunities that match employees' career goals, supporting this process through regular interviews between employees and supervisors or as part of mentoring sessions, in order to understand career goals and opportunities that attract employees. Furthermore, the organization can also conduct job rotation to enable employees to develop knowledge and skills in various work areas to reveal employees' actual interests. Bravo et al. (2011) found that participation in job rotation and job enrichment programs relates positively to PCO. Thus, to retain employees, organizations should offer job rotations that allow employees to learn about possible jobs and develop social contacts across different organizational departments. Ultimately, the organization might conduct a review, if possible, to discover how employees perceived various jobs and their job-field preferences. Thus, the organization can place 
employees in the field of work that best fits their career goals and provides the right career opportunity.

\section{Limitations and Future Direction}

This study has several limitations. All measurements were self-reported, possibly increasing common method bias. However, tests of common method variance showed little possibility of CMV affecting this research. Furthermore, we also showed our study variables' discriminant validity using CFA analyses. However, future research is suggested to collect data from other sources, such as supervisors' evaluations of an organization's career opportunities or by employing temporal separation of data collection in which predictor, mediator, and outcome variables are collected at different times. Another study limitation is the correlational design that limits the ability to confirm causal relations among variables. Future research might consider using experimental or longitudinal studies to ensure causal relations between variables.

\section{Conclusion}

This study's result showed that fit and sacrifice dimensions of organizational embeddedness mediated the relation between PCO and turnover intention. Furthermore, this study found that fit, links, and sacrifice dimensions together mediated the relation between PCO and turnover intention. The study contributes to the literature by showing the complete mediating effect of fit, links, and sacrifice dimensions of organizational embeddedness.

\section{References}

Aamodt, M. G. (2010). Industrial/organizational psychology: An applied approach. 6th edition. California: Wadsworth.

Allen, D. G., Moffitt, K. R., \& Weeks, K. P. (2005). Turnover intentions and voluntary turnover: The moderating roles of self-monitoring, locus of control, proactive personality, and risk aversion. Journal of Applied Psychology, 90, 980-990. doi:10.1037/0021-9010.90.5.980.

Arruda, W. (2017, August 2). The surprising thing millennials want from their career. Retrieved from https://www.forbes.com/sites/williamarruda/2017/08/02/the-surprising-thing-millennials-want-fromtheir-career/\#7ba406e24fce.

Ashkanasy, N. M., Lievens, F., McElroy, J. C., Wang, Q., \& Weng, Q. (2014). Organizational career growth and subsequent voice behavior: The role of affective commitment and gender. Journal of vocational behavior, 84, 431-441. doi: 10.1016/j.jvb.2014.03.004.

Atan, T. A \& Purba, D. E. (2018). The role of job embeddeness as a mediator in in the relationship between job demand resources and turnover intentions. In A. A. Ariyanto, H. Muluk, P. Newcombe, F. P. Piercy, E. K. Poerwandari, \& S. H. R. Suradijono (Eds), Diversity in Unity: Perspective from Psychology and Behavioral Sciences (pp. 381-387). London: Taylor \& Francis Group.

Baer, M. D., Colquitt, J. A., Halvorsen-Ganepola, M., \& Long, D. M., (2014). Scale indicators of social exchange relationships: A comparison of relative content validity. Journal of Applied Psychology, 99, 599-618. doi:http://dx.doi.org/10.1037/a0036374. doi:10.1037/a0036374.

Bakker, A. B., \& Schaufeli, W. B. (2004). Job demands, job resources, and their relationship with burnout and engagement: A multi-sample study. Journal of organizational Behavior, 25, 293-315. doi: 10.1002/job.248.

Banister, C., Meriac, J. P., \& Woehr, D. J. (2010). Generational differences in work ethic: An examination of measurement equivalence across three cohorts. Journal of Business and Psychology, 25, 315-324. doi: 10.1007/s10869-010-9164-7. 
Bedeian, A. G., Kemery, E. R., \& Pizzolatto, A. B. (1991). Career commitment and expected utility of present job as predictors of turnover intentions and turnover behavior. Journal of Vocational Behavior, 39, 331-343. doi: 10.1016/0001-8791(91)90042-K.

Bentler, P. M., \& Hu, L. T. (1999). Cutoff criteria for fit indexes in covariance structure analysis: Conventional criteria versus new alternatives. Structural equation modeling: a multidisciplinary journal, 6, 1-55. doi: $10.1080 / 10705519909540118$.

Bernardin, H. J., Dahmus, S. A., Johnson, D. L., \& Villanova, P. (1994). The validity of a measure of job compatibility in the prediction of job performance and turnover of motion picture theater personnel. Personnel Psychology, 47, 73-90. doi: 10.1111/j.1744-6570.1994.tb02410.x

Blau, P. M. (1964). Exchange and power in social life. New York: Routledge.

Born, M. P., Oostrom, J. K., Purba, D. E., \& van der Molen, H. T. (2016). The Relationships Between Trust in Supervisor, Turnover Intentions, and Voluntary Turnover. Journal of Personnel Psychology, 174-183. doi: 10.1027/1866-5888/a000165.

Bravo, J., Kraimer, M. L., Liden, R. C., Seibert, S. E., \& Wayne, S. J. (2011). Antecedents and outcomes of organizational support for development: the critical role of career opportunities. Journal of Applied Psychology, 96, 485-500. doi: 10.1037/a0021452.

Burch, T. C., Lee, T.W., \& Mitchell, T. R. (2014). The story of why we stay: A review of job embeddedness. Annual Review of Organizational Psychology and Organizational Behavior, 1, 199-216. doi: 10.1146/annurev-orgpsych-031413-091244.

Chan, D. (1996). Cognitive misfit of problem-solving style at work: A facet of person-organization fit. Organizational Behavior and Human Decision Processes, 68, 194-207. doi: 10.1006/obhd.1996.0099.

Chi, C. G., Gursoy, D., \& Maier, T. A. (2008). Generational differences: An examination of work values and generational gaps in the hospitality workforce. International Journal of Hospitality Management, 27, 448458. doi: 10.1016/j.ijhm.2007.11.002.

Cordery, J., Gamble, J., \& Tian, A. W. (2016). Staying and performing: How human resource management practices increase job embeddedness and performance. Personnel Review, 45, 947-968. doi: 10.1108/PR09-2014-0194.

Dwaikat, N., Queiri, A., \& Yusoff, W. F. W. (2014). Generation-Y employees' turnover: Work-values fit perspective. International Journal of Business and Management, 9, 199. doi: 10.5539/ijbm.v9n11p199.

Eisenberger, R., \& Rhoades, L. (2002). Perceived organizational support: a review of the literature. Journal of Applied Psychology, 87, 698-714. doi: 10.1037//0021-9010.87.4.698.

Erez, M., Holtom, B. C., Lee, T. W., Mitchell, T. R., \& Sablynski, C. J. (2001). Why people stay: Using job embeddedness to predict voluntary turnover. Academy of management journal, 44, 1102-1121. doi: $10.2307 / 3069391$

Ertas, N. (2015). Turnover intentions and work motivations of millennial employees in federal service. Public Personnel Management, 44, 401-423. doi:10.1177/0091026015588193.

Forzano, L. B., \& Gravetter, F. J. (2012). Research Methods for the Behavioral Science. USA: Wadsworth.

Griffeth, R. W., Hom, P. W., Lee, T. W., \& Mitchell, T. R. (2012). Reviewing employee turnover: focusing on proximal withdrawal states and an expanded criterion. Psychological bulletin, 831-858. doi: $10.1037 / \mathrm{a} 0027983$.

Halbesleben, J. R., Neveu, J. P., Paustian-Underdahl, S. C., \& Westman, M. (2014). Getting to the "COR" understanding the role of resources in conservation of resources theory. Journal of Management, 40, 13341364. doi: 10.1177/0149206314527130.

Harris, G. (2016, September 16). 4 truths you need to know about millenial job hopping. Retrieved from https://www.entrepreneur.com/article/281663.

Harris, K. J., Kacmar, K. M., \& Wheeler, A. R. (2011). The mediating role of organizational job embeddedness in the LMX-outcomes relationships. The Leadership Quarterly, 22, 271-281. doi:10.1016/j.leaqua.2011.02.003.

Henneberger, F., \& Sousa-Poza, A. (2004). Analyzing job mobility with job turnover intentions: An international comparative study. Journal of Economic Issues, 38, 113-137. doi: 10.1080/00213624.2004.11506667.

Hisham, R., Queiri, A., Yusoff, W. W., \& Zakaria, S. (2013). Generation-Y turnover intention in business process outsourcing sector. Kota Kinabalu, ICMEF. doi: 10.13140/2.1.1577.6001. 
Hobfoll, S. E. (1989). Conservation of resources: A new attempt at conceptualizing stress. American Psychologist, 44, 513-524. doi: 10.1037/0003-066X.44.3.513.

Hollingswort, A.T., Horner, O. S., \& Mobley, W. H. (1978). An evaluation of precursors of hospital employee turnover. Journal of Applied Psychology, 63, 408-414. doi: 10.1037/0021-9010.63.4.408.

Huber, A. F. (2017). Proactive Personality and Voluntary Turnover: The Moderating Effects of Development and Perceived Career Opportunities (Master thesis). Illinois State University, Illinois.

Jiang, K., Liu, D., Mitchell, T. R., McKay, P. F., \& Lee, T. W. (2012). When and how is job embeddedness predictive of turnover? a meta-analytic investigation. Journal of Applied Psychology, 97, 1077-1056. doi: $10.1037 / \mathrm{a} 0028610$.

Kao, D., \& Kim, H. (2014). A meta-analysis of turnover intention predictors among US child welfare workers. Children and Youth Services Review, 47, 214-223. doi: 10.1016/j.childyouth.2014.09.015.

Lee, J., MacKenzie S. B., Podsakoff, N. P., \& Podsakoff, P. M. (2003). Commmon Method Biases in Behavioral Research: A Critical Review of the Literature and Recommended Remedies. Journal of Applied Psychology, 88, 879-903. doi: 10.1037/0021-9010.88.5.879.

Michael P. (2015). Michael Page Indonesia Employee Intentions Report. Retrieved from http://www.michaelpage.co.id.

Purba, D. E. (2015). Employee embeddedness and turnover intentions: Exploring the moderating effects of commute time and family embeddedness. Hubs-Asia, 9, 39-51. doi: 10.7454/mssh.v19i1.181.

Rosseel, Y. (2012). Lavaan: An R package for structural equation modeling and more. Version 0.5-12 (BETA). Journal of statistical software, 48, 1-36. doi: 10.18637/jss.v048.i02.

Tramonte, L. L. (2012). Generation Y: the misunderstood generation (Master's Thesis). Southeastern Louisiana University Hammond, Louisiana. 